\title{
Comparative Study of Dc To Dc Converters Via Simpowerelectronics Fuel Cell Stack
}

\author{
Sandeep Gupta ${ }^{* 1}$, Swati Singh ${ }^{2}$, Lini Mathew ${ }^{3}$, Shimi S. L. ${ }^{4}$ \\ ${ }^{* 1}$ Asst.Prof. , Dept. of ECE, Bharat Institute of Technology, Meerut, India \\ ${ }^{2}$ Asst.Prof. , Dept. of ECE, Meerut Institute of Technology, Meerut, India \\ ${ }^{3}$ Associate.Prof., Dept. of EE, NITTTR, Chandigarh, India \\ ${ }^{4}$ Asst.Prof. , Dept. of EE, NITTTR, Chandigarh, India
}

\begin{abstract}
In this paper, a comparative study is done for dc to dc converters. DC to DC converters are used to change the output voltage at desired level either less or more from input voltage. These converters are very useful while connecting the dc sources like PV panel and Fuel cell stack with the load. These converters also perform the task of load matching so that maximum power can be utilized. Modeling of DC to DC converters is done using MATLAB/SimPowersystem. For simulation, $1.26 \mathrm{KW}$ and $50 \mathrm{~K}$ W PEM Fuel cell stack is taken from SimPowersystem library.
\end{abstract}

\section{Keywords: - Fuel Cell, dc to dc Converter, PI Controller, MATLAB/SIMULINK}

\section{INTRODUCTION}

The dc power is obtained from an existing power supply network or from a rotating alternator, a rectifier or a battery, fuel cell, photovoltaic array or magneto hydrodynamic generator. To control the output voltage or to get constant output voltage if input voltage is changing. DC to DC converter is also used as an interface device between DC supply system and Load. This performs the task of load matching for maximum power transfer as in PV array.

There are a number of different topologies for DC-DC converters. They are categorized into isolated or non-isolated topologies. The isolated topologies use a small-sized high-frequency electrical isolation transformer which provides the benefits of DC isolation between input and output, and step up or down of output voltage by changing the transformer turns ratio. They are very often used in switch-mode DC power supplies. Non-isolated topologies do not have isolation transformers. They are almost always used in DC motor drives. These topologies are further categorized into three types: step down (buck), step up (boost), and step up \& down (buck-boost). The buck topology is used for voltage step-down. In PV applications, the buck type converter is usually used for charging batteries and in LCB for water pumping systems. The boost topology is used for stepping up the voltage. The grid-tied systems use a boost type converter to step up the output voltage to the utility level before the inverter stage. Then, there are topologies able to step up and down the voltage such as: buck-boost and Cuk For PV system with batteries, the MPP of commercial PV module is set above the charging voltage of batteries for most combinations of irradiance and temperature. A buck converter can operate at the MPP under most conditions, but it cannot do so when the MPP goes below the battery charging voltage under a low-irradiance and high-temperature condition. Thus, the additional boost capability can slightly increase the overall efficiency.

\section{FUEL CELL}

In this fast, modern age and rapidly increasing population with ongoing fully automation world, requirement of energy sources is also increases. Due to the limited source and increasing pricing of the nonrenewable energy along with the global environment issue. This improves public awareness of environmental protection for the fulfillment of energy requirement. Always keep in mind about the environmental issue only possible is to start using more and more renewable energy sources.

\subsection{TYPES OF RENEWABLE ENERGY}

1. Solar energy 2.Wind energy 3.Bio-energy 4.hydro power energy 5.Ocean energy 6.Hydrogen and fuel cells.

\subsection{WORKING PRINCIPLE OF FUELL CELL}

The fuel and oxidant is to be fed continuously. The electrolyte which acts like a membrane permits only the positive ions to flow from anode to cathode and acts as an insulator for electrons. The electron produced from the hydrogen fuel after it decomposed tries to get stable by going to cathode side which is accomplished by an external circuit. And this way an electricity in generated. 


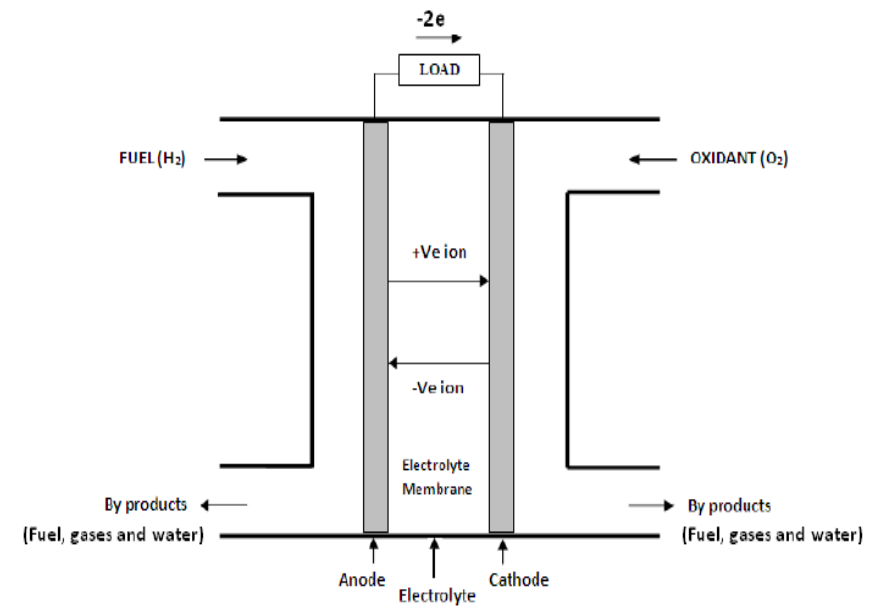

Fig.1 Basic Working of fuel cell

The reactions take place in the fuel cell are:

Anode reaction:

$\mathrm{H}_{2}=\mathbf{2} \boldsymbol{H}^{+}+\mathbf{2} \boldsymbol{e}^{-}$

Cathode reaction:

$\frac{1}{2} \mathrm{O}_{2}+2 \mathrm{H}^{+}+2 e^{-}=>\mathrm{H}_{2} \mathrm{O}$

Overall reaction:

$$
\mathrm{H}_{2}+\frac{1}{2} \mathrm{O}_{2}=>\mathrm{H}_{2} \mathrm{O}
$$

Different types of fuel cells are categorized according to the electrolyte used: Proton-Exchange-Membrane (PEM) fuel cells, alkaline fuel cells, phosphoric acid fuel cells, molten carbonate fuel cells, and solid oxide fuel cells. The V-I characteristics of basic Full cell is shown in Fig.3. Detailed models are now available in literature for fuel cell $[10,11]$. Some models for fuel cell are available in MATLAB/SIMULINK. Since the purpose of this paper isn't the fuel cell modeling, these preset models will be used in all simulation. Fig 3. Shows the PEMFC fuel cell of $1.26 \mathrm{~kW}, 24 \mathrm{~V}$.

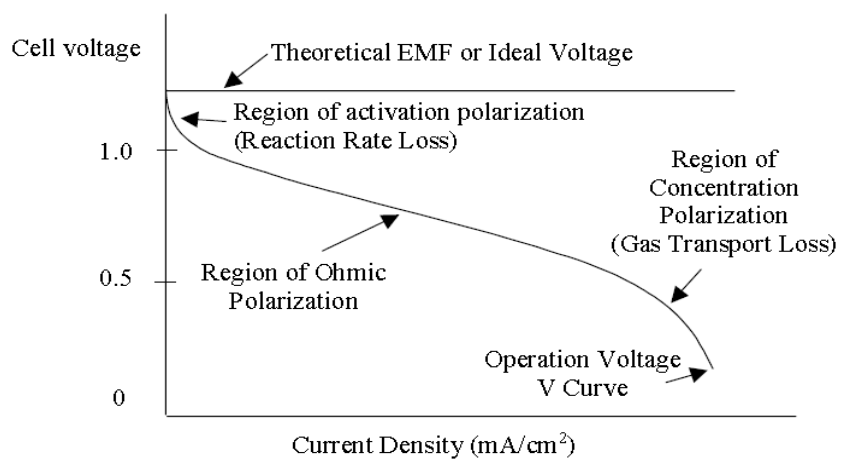

Fig.2 V-I charactristcs of Fuel Cell

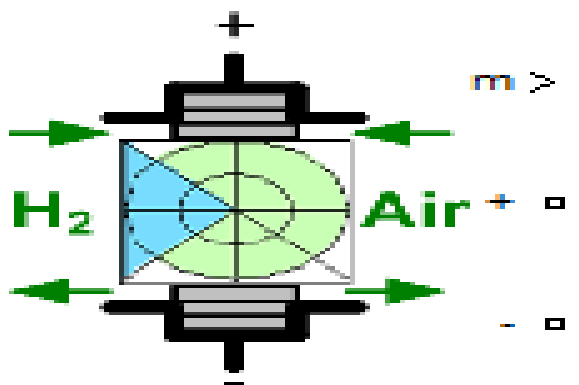

Fig.3 PEM Fuel Cell (1.26 KW, 24 V) 


\section{DC TO DC CONVERTERS}

A DC-DC converter is a circuit that converts DC voltage from one voltage level to another or we can say converting the unregulated DC input to a controlled DC output at a desired voltage level. DC-DC converters are now a day's present in all the electronic devices such as laptop, iPod etc. As all the devices have a single power supply battery which is to be converted to a different voltage level of sub-circuits, which simply reduces the space and cost of extra batteries. Fuel cell output voltage shows a sagging characteristic and gets affected by the load variation or by changes in supply need. So it is a very necessary part of circuit to enhance the power supply and keep it at a constant level. The step-down and the step-up are the basic converter topologies. The buck-boost and the cuk are combinations of above two topologies.

\subsection{BUCK CONVERTER:}

The buck converter with ideal switching devices will be considered here which is operating with the switching period of $\mathrm{T}$ and duty cycle $\mathrm{D}$. The state equations corresponding to the converter in continuous conduction mode (CCM) can be easily understood by applying Kirchhoff's voltage law on the loop containing the inductor and Kirchhoff's current law on the node with the capacitor branch connected to it. When the ideal switch is $\mathrm{ON}$, the dynamics of the inductor current $i_{L}(t)$ and the capacitor voltage $v_{C}(t)$ are given by,

$$
\left\{\begin{array}{l}
\frac{d i_{L}}{d t}=\frac{1}{L}\left(V_{i n}-v_{o}\right) \\
\frac{d v_{o}}{d t}=\frac{1}{C}\left(i_{L}-\frac{v_{o}}{R}\right)
\end{array}\right.
$$

and when the switch is OFF are presented by,

$$
\left\{\begin{array}{l}
\frac{d i_{L}}{d t}=\frac{1}{L}\left(-v_{o}\right) \\
\frac{d v_{o}}{d t}=\frac{1}{C}\left(i_{L}-\frac{v_{o}}{R}\right)
\end{array}, \quad d T<t<T, \quad Q:\right. \text { OFF }
$$

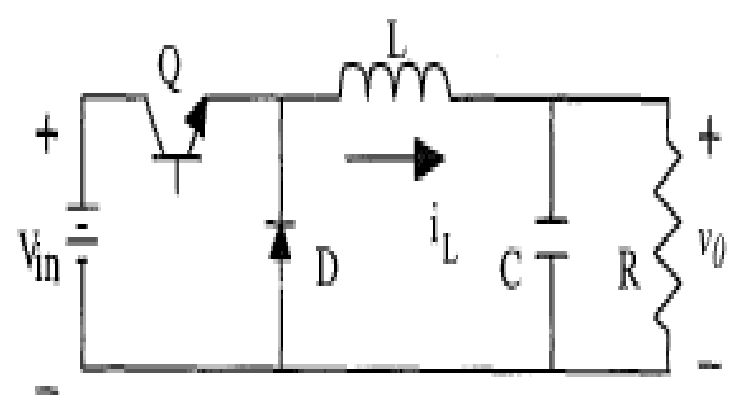

Fig. 4 Buck Converter

\subsection{BOOST CONVERTER:}

The boost converter of Fig. 3 with a switching period of $\mathrm{T}$ and a duty cycle of $\mathrm{D}$ is given. Again, assuming continuous conduction mode of operation, the state space equations when the main switch is ON are shown by.

$$
\left\{\begin{array}{l}
\frac{d i_{L}}{d t}=\frac{1}{L}\left(V_{i n}\right) \\
\frac{d v_{o}}{d t}=\frac{1}{C}\left(-\frac{v_{o}}{R}\right)
\end{array}, \quad 0<t<d T, \quad Q: O N\right.
$$

and when the switch is OFF

$$
\left\{\begin{array}{l}
\frac{d i_{L}}{d t}=\frac{1}{L}\left(V_{i n}-v_{o}\right) \\
\frac{d v_{o}}{d t}=\frac{1}{C}\left(i_{L}-\frac{v_{o}}{R}\right)
\end{array}, \quad d T<t<T, \quad Q:\right. \text { OFF }
$$




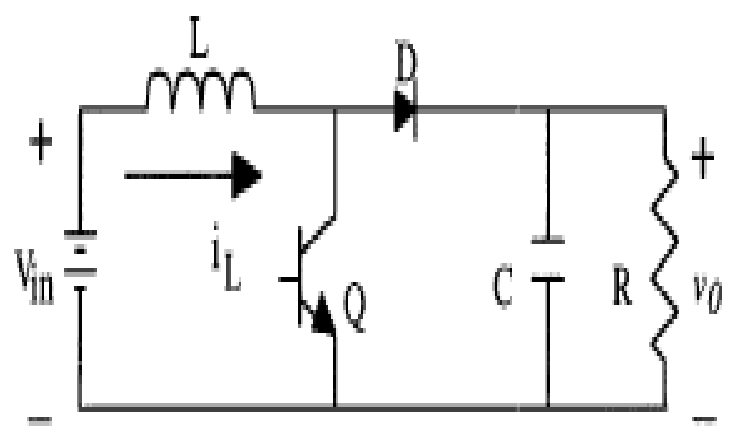

Fig.5 Boost Converter

\subsection{BUCK-BOOST CONVERTER :}

In Fig. 5 a DC-DC buck-boost converter is shown. The switching period is T and the duty cycle is D. Assuming continuous conduction mode of operation, when the switch is $\mathrm{ON}$, the state space equations are given by,

$\left\{\begin{array}{l}\frac{d i_{L}}{d t}=\frac{1}{L}\left(V_{i n}\right) \\ \frac{d v_{o}}{d t}=\frac{1}{C}\left(-\frac{v_{o}}{R}\right)\end{array}, \quad 0<t<d T, \quad Q: O N\right.$

and when the switch is OFF

$\left\{\begin{array}{l}\frac{d i_{L}}{d t}=\frac{1}{L}\left(v_{o}\right) \\ \frac{d v_{o}}{d t}=\frac{1}{C}\left(-i_{L}-\frac{v_{o}}{R}\right)\end{array}, \quad d T<t<T, \quad Q:\right.$ OFF

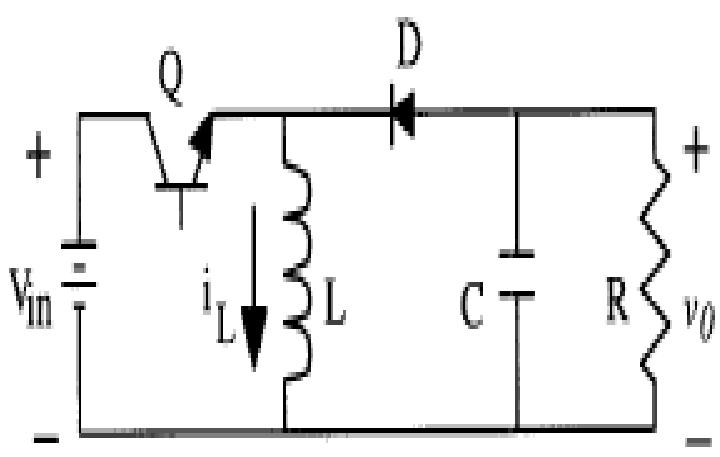

Fig.6 Buck Boost Converter

\subsection{CUK CONVERTER:}

The Cuk converter of Fig. 7 with switching period of $\mathrm{T}$ and duty cycle of $\mathrm{D}$ is considered. During the continuous conduction mode of operation, the state space equations are as follows,

$$
\left\{\begin{array}{l}
\frac{d i_{L 1}}{d t}=\frac{1}{L_{1}}\left(v_{i n}\right) \\
\frac{d v_{c}}{d t}=\frac{1}{C_{2}}\left(-i_{L 2}\right) \\
\frac{d i_{L 2}}{d t}=\frac{1}{L_{2}}\left(-v_{o}+v_{c}\right) \\
\frac{d v_{o}}{d t}=\frac{1}{C_{1}}\left(i_{L 2}-\frac{v_{o}}{R}\right)
\end{array}\right.
$$

When the switch is OFF 


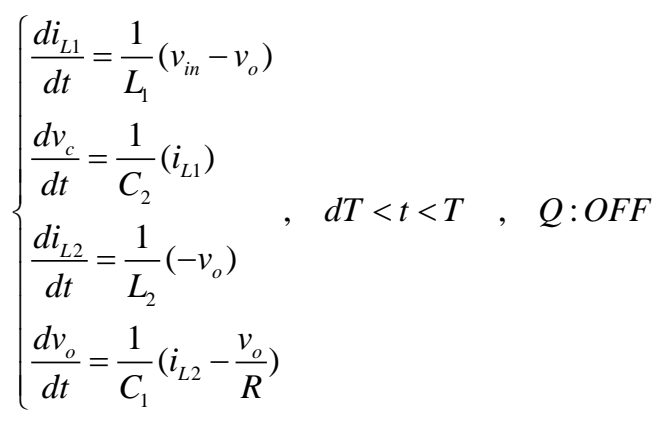

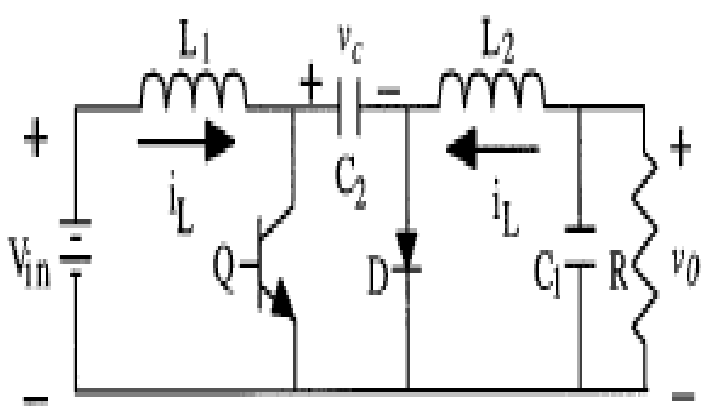

Fig.7 Cuk Converter

\section{PID CONTROLLER}

A proportional-integral-derivative controller (PID controller) is a generic control loop feedback mechanism (controller) widely used in industrial control systems. A PID controller calculates an "error" value as the difference between a measured process variable and a desired set point. The controller attempts to minimize the error by adjusting the process control inputs. The PID controller calculation algorithm involves three separate constant parameters, and is accordingly sometimes called three-term control: the proportional, the integral and derivative values, denoted P, I, and D. Simply put, these values can be interpreted in terms of time: $\mathrm{P}$ depends on the present error, I on the accumulation of past errors, and $\mathrm{D}$ is a prediction of future errors, based on current rate of change. The weighted sum of these three actions is used to adjust the process via a control element such as the position of a control valve, a damper, the power supplied to a heating element and controlling the duty cycle of dc to dc converter. Here we used PI controller for controlling duty cycle.

\section{SIMULINK MODELS OF DC TO DC COVERTERS WITH FUEL CELL STACK}

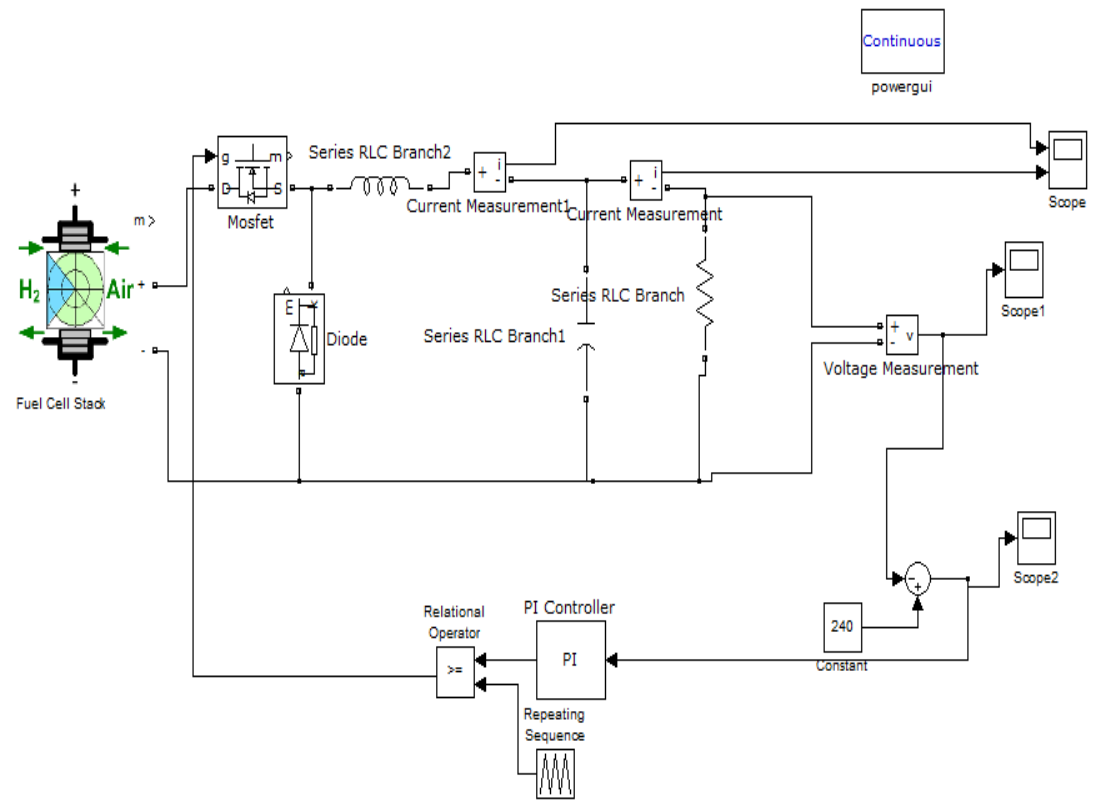

Fig.8 Buck Converter 


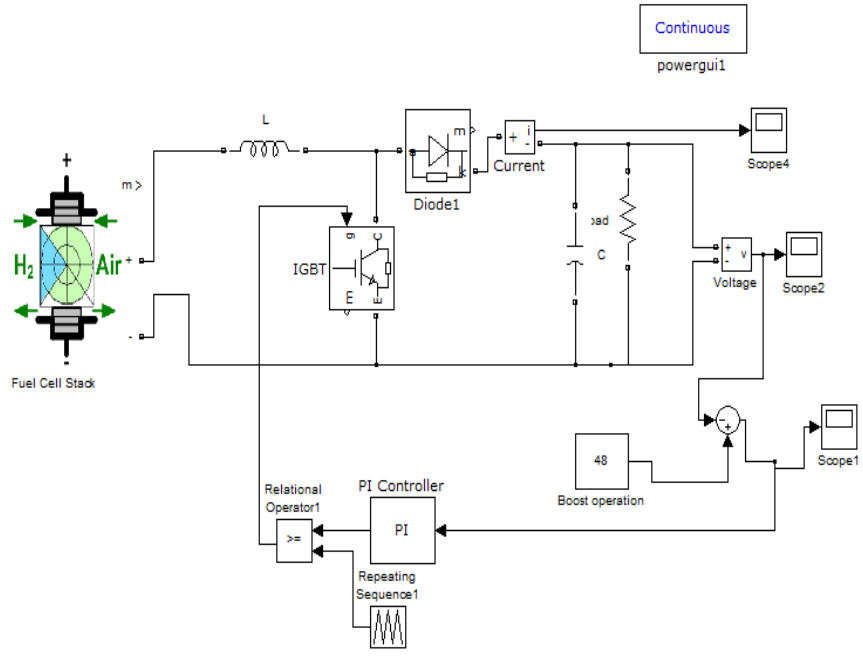

Fig.9 Boost Converter

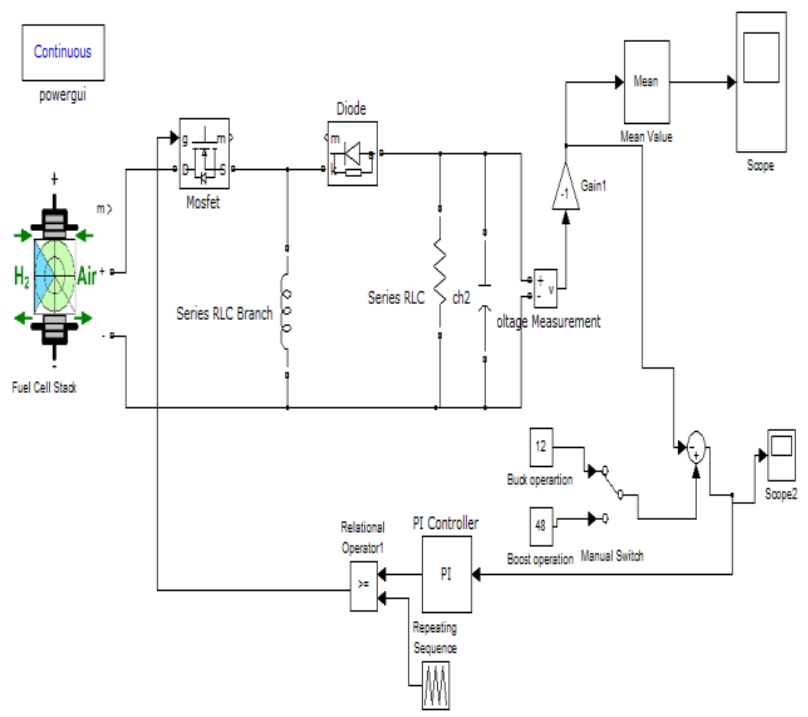

Fig.10 Buck-Boost Converter

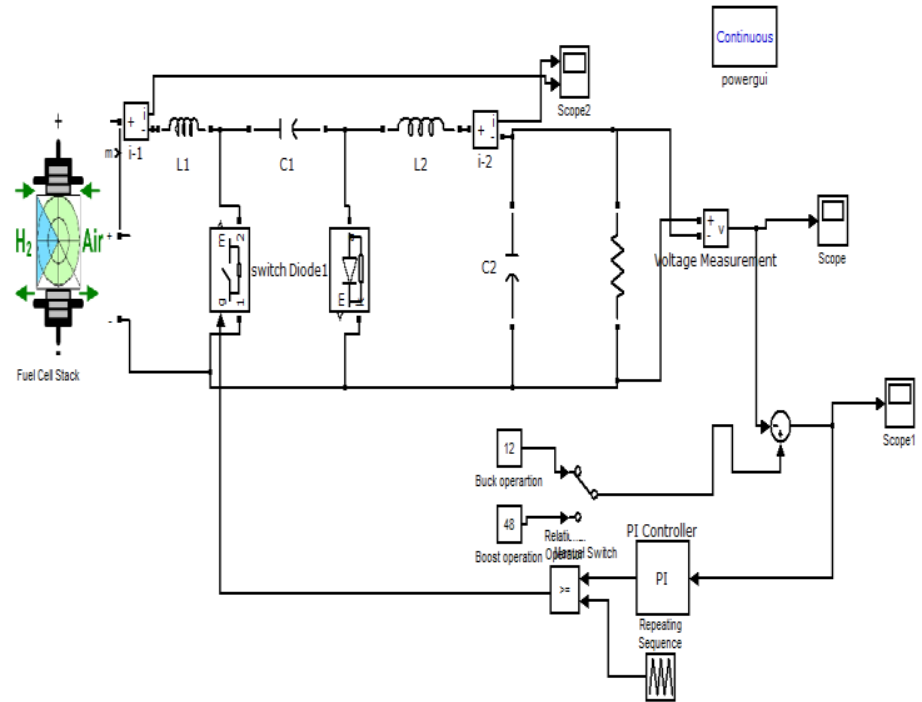

Fig.11 Cuk Converter 


\section{SIMULATION AND RESULTS}

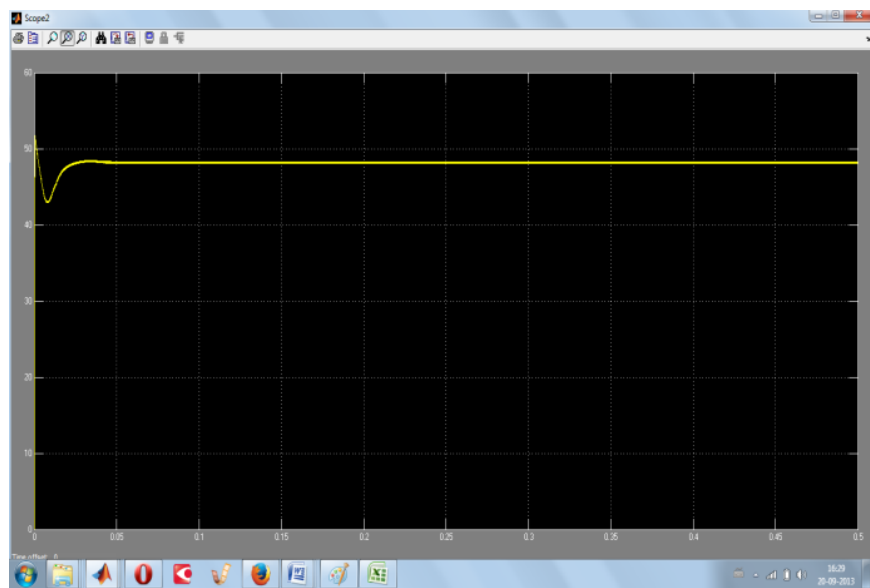

Fig.12 Boost Converter (24 V to $48 \mathrm{~V})$

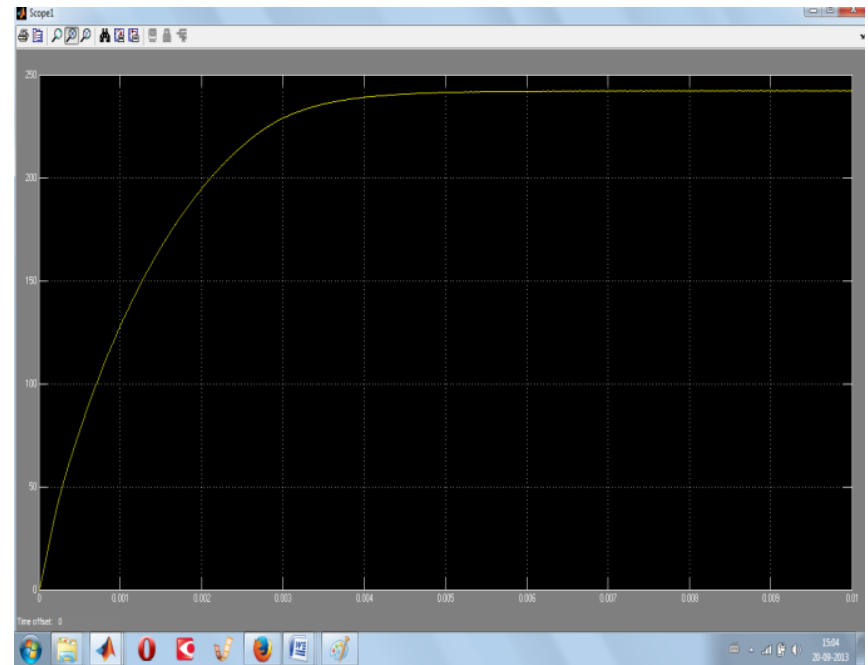

Fig.13 Buck Converter (625V to $240 \mathrm{~V})$

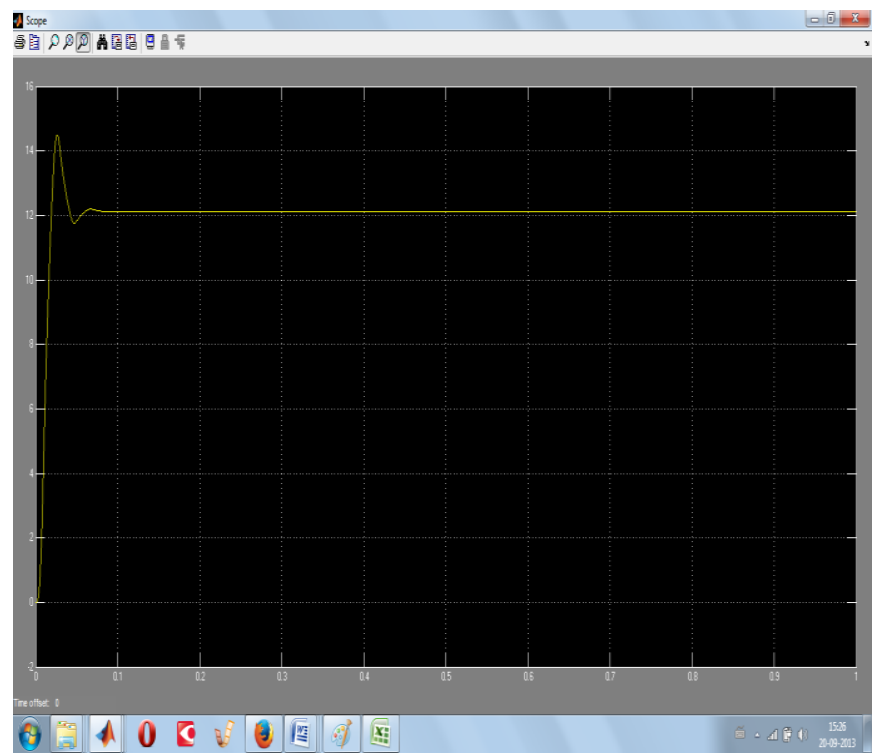

Fig.14 Buck Operation (Buck-Boost) (24 V to $12 \mathrm{~V})$ 


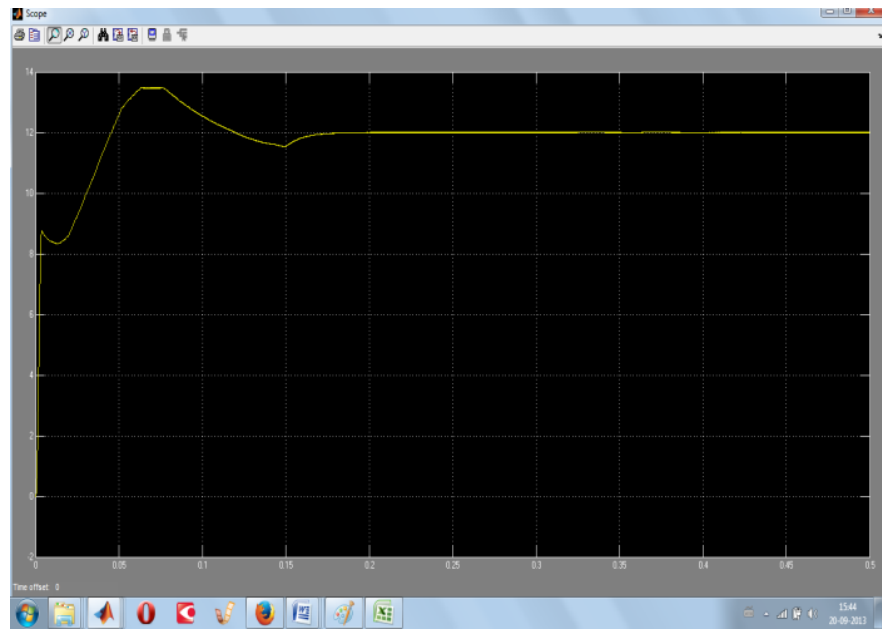

Fig.15 Buck Operation (Cuk converter) (24 V to $12 \mathrm{~V})$

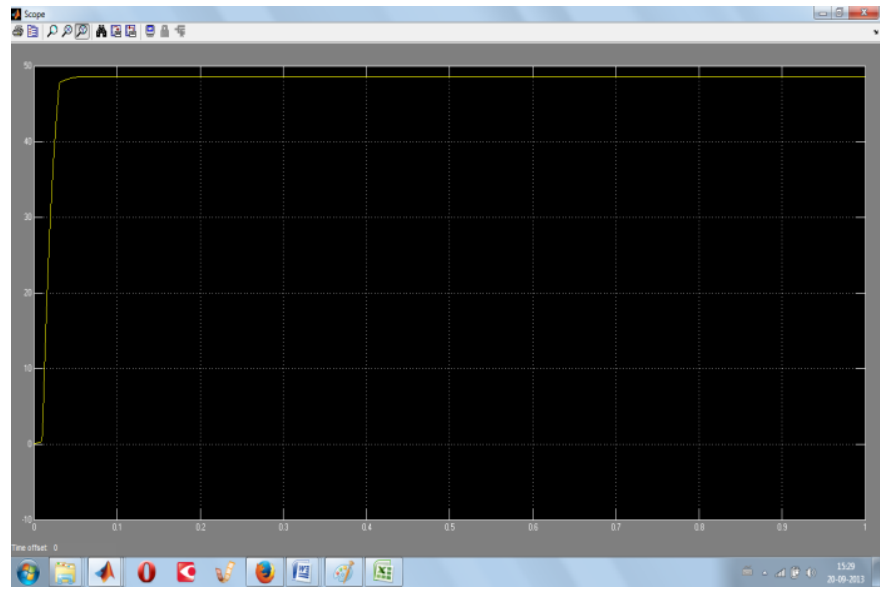

Fig.16 Boost Operation (Buck-Boost) (24 V to $48 \mathrm{~V})$

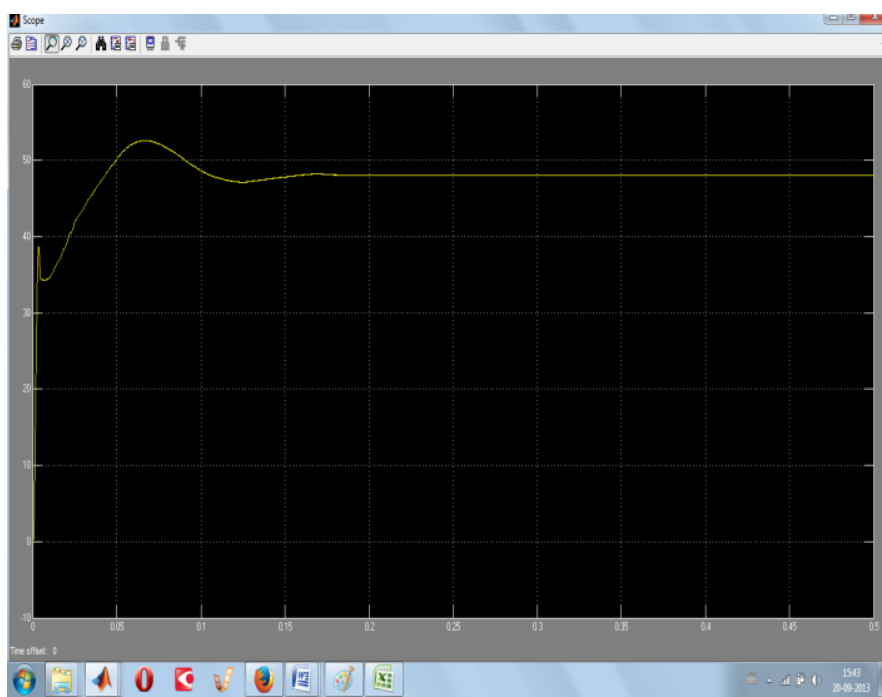

Fig.17 Boost Operation (Cuk converter) (24 V to $48 \mathrm{~V})$

\section{CONCLUSION}

In this paper, different types of DC-DC converter are simulated in MATLAB/SIMULINK. The Boost converter has the highest efficiency as is give output voltage greater than the input, but when it is desired to have a lower output voltage during now power need it fail and similarly the Buck converter. So the Buck-Boost and cuk converter topology are used which can give both the higher and lower output voltage. 


\section{REFERENCES}

[1] A. Kirubakaran, Shailendra Jain, R.K. Nema, A review on fuel cell technologies and power electronic interface, Renewable and Sustainable Energy Reviews 13 (2009) 2430-2440.

[2] Boudghene SA, Traversa E.,Fuel cells, an alternative to standard sources of energy. Renew Sustain Energy Rev 2002; 6:297-306.

[3] Farooque M, Maru HC. Fuel cells-the clean and efficient power generators. IEEE Proc2001;89:181929.

[4] J.Mahdavi, A.Emadi, H.A.Toliyat, Application of State Space Averaging Method to Sliding Mode Control of PWM DC/DC Converters, IEEE Industry Applications Society October 1997.

[5] N. Mohan, T. Undeland, W. Robbins, Power Electronics Converters, Applications and Design, ISBN 9814-12-692-6.

[6] Blaabjerg F, Chen Z, Kjaer SB. Power electronics as efficient interface in dispersed power generation systems. IEEE Trans Power Electron 2004; 19:1184-94.

[7] http://en.wikipedia.org/wiki/DC-to-DC converter.

[8] Muhammad H. Rashid, Power Electronics Handbook, Academic Press, US. 